\title{
Removal of Hydrogen Peroxide Residuals and By-Product Bromate from Advanced Oxidation Processes by Granular Activated Carbon
}

\author{
Feifei Wang ${ }^{1,2, *(\mathbb{D},}$, Lu Zhang ${ }^{1}$, Liangfu Wei ${ }^{2, *}$ and Jan Peter van der Hoek ${ }^{2,3}$ (D) \\ 1 Department of Environmental Science and Engineering, School of Environmental and Chemical Engineering, \\ Shanghai University, Shanghai 200444, China; wff1986@163.com \\ 2 Department of Water Management, Faculty of Civil Engineering and Geosciences, Delft University of Technology, \\ P.O. Box 5048, 2600 GA Delft, The Netherlands; j.p.vanderhoek@tudelft.nl \\ 3 Research \& Innovation Program, Waternet, Korte Ouderkerkerdijk 7, 1096 AC Amsterdam, The Netherlands \\ * Correspondence: feifeiwang@shu.edu.cn (F.W.); L.Wei-1@tudelft.nl (L.W.); Tel.: +86-021-661-377-46 (F.W.); \\ +31-152-78-65-88 (L.W.)
}

Citation: Wang, F.; Zhang, L.; Wei, L.; van der Hoek, J.P. Removal of Hydrogen Peroxide Residuals and By-Product Bromate from Advanced Oxidation Processes by Granular Activated Carbon. Water 2021, 13, 2460. https://doi.org/10.3390/ w13182460

Academic Editor: Stefanos Giannakis

Received: 28 July 2021

Accepted: 2 September 2021

Published: 7 September 2021

Publisher's Note: MDPI stays neutral with regard to jurisdictional claims in published maps and institutional affiliations.

Copyright: (c) 2021 by the authors. Licensee MDPI, Basel, Switzerland. This article is an open access article distributed under the terms and conditions of the Creative Commons Attribution (CC BY) license (https:/ / creativecommons.org/licenses/by/ $4.0 /)$.

\begin{abstract}
During drinking water treatment, advanced oxidation process (AOP) with $\mathrm{O}_{3}$ and $\mathrm{H}_{2} \mathrm{O}_{2}$ may result in by-products, residual $\mathrm{H}_{2} \mathrm{O}_{2}$ and $\mathrm{BrO}_{3}{ }^{-}$. The water containing $\mathrm{H}_{2} \mathrm{O}_{2}$ and $\mathrm{BrO}_{3}{ }^{-}$often flows into subsequent granular activated carbon (GAC) filters. A concentrated $\mathrm{H}_{2} \mathrm{O}_{2}$ solution can be used as GAC modification reagent at $60^{\circ} \mathrm{C}$ to improve its adsorption ability. However, whether low concentrations of $\mathrm{H}_{2} \mathrm{O}_{2}$ residuals from AOP can modify GAC, and the impact of $\mathrm{H}_{2} \mathrm{O}_{2}$ residuals on $\mathrm{BrO}_{3}{ }^{-}$removal by the subsequent GAC filter at ambient temperature, is unknown. This study evaluated the modification of GAC surface functional groups by residual $\mathrm{H}_{2} \mathrm{O}_{2}$ and its effect on $\mathrm{BrO}_{3}{ }^{-}$removal by GAC. Results showed that both $\mathrm{H}_{2} \mathrm{O}_{2}$ and $\mathrm{BrO}_{3}{ }^{-}$were effectively removed by virgin GAC, while pre-loaded and regenerated GACs removed $\mathrm{H}_{2} \mathrm{O}_{2}$ but not $\mathrm{BrO}_{3}{ }^{-}$anymore. At the ambient temperature $150 \mu \mathrm{mol} / \mathrm{L} \mathrm{H}_{2} \mathrm{O}_{2}$ residuals consumed large amounts of functional groups, which resulted in the decrease of $\mathrm{BrO}_{3}{ }^{-}$removal by virgin GAC in the presence of $\mathrm{H}_{2} \mathrm{O}_{2}$ residuals. Redox reactions between $\mathrm{BrO}_{3}{ }^{-}$and surface functional groups played a dominant role in $\mathrm{BrO}_{3}{ }^{-}$ removal by GAC, and only a small amount of $\mathrm{BrO}_{3}{ }^{-}$was removed by GAC adsorption. The higher the $\mathrm{pH}$, the less $\mathrm{BrO}_{3}{ }^{-}$removal and the more $\mathrm{H}_{2} \mathrm{O}_{2}$ removal was observed.
\end{abstract}

Keywords: bromate; granular activated carbon; hydrogen peroxide; surface functional groups; ozone

\section{Introduction}

The combination of an advanced oxidation process (AOP) as a pre-treatment with subsequent managed aquifer recharge (MAR) has been suggested as a comprehensive treatment system to effectively remove various organic micro-pollutants (OMPs) during drinking water production [1,2]. However, a disadvantage of applying ozone-based AOP is the formation of bromate $\left(\mathrm{BrO}_{3}{ }^{-}\right)$[3-5], a genotoxic carcinogen [6], when bromide $\left(\mathrm{Br}^{-}\right)$ is contained in the water. WHO, USEPA, and the European Union have set drinking water regulations for the maximum allowable concentration of $\mathrm{BrO}_{3}{ }^{-}$at $0.078 \mu \mathrm{mol} / \mathrm{L}$ $(10 \mu \mathrm{g} / \mathrm{L})$ [7-9]. In order to reduce the formation of $\mathrm{BrO}_{3}{ }^{-}$, hydrogen peroxide $\left(\mathrm{H}_{2} \mathrm{O}_{2}\right)$ may be dosed excessively during AOP $[10,11]$. Since $\mathrm{H}_{2} \mathrm{O}_{2}$ contained in the effluent of ozonebased AOP may cause undesired effects to the ecosystem of subsequent MAR systems [12], it needs to be quenched to a low concentration before flowing into the MAR systems. Therefore, a subsequent removal process may be required for both of $\mathrm{BrO}_{3}{ }^{-}$and $\mathrm{H}_{2} \mathrm{O}_{2}$ control [13].

A recent study reported that the adsorption-based physical method has been proven to be more effective for $\mathrm{BrO}_{3}{ }^{-}$removal than chemical methods in potable water treatment [14]. Granular activated carbon (GAC) has been used as a powerful adsorbent in water treatment and some drinking water companies use GAC filters to quench the excessive $\mathrm{H}_{2} \mathrm{O}_{2}$ from 
AOP [15]. GAC and modified GAC also have been shown to decrease $\mathrm{BrO}_{3}{ }^{-}$formation [16] or remove $\mathrm{BrO}_{3}{ }^{-}$in a number of studies [17-19]. The previous studies focused on the effects of carbon type, $\mathrm{pH}$, temperature, empty bed contact time, source water, natural organic matter (NOM) and other anions on $\mathrm{BrO}_{3}{ }^{-}$removal through kinetic and isotherm tests $[17,20]$. Previous studies found that $\mathrm{BrO}_{3}{ }^{-}$could be effectively removed by virgin GAC, while some studies revealed that after a certain running time, the loaded and/or regenerated $\mathrm{GAC}$ was no longer effective for $\mathrm{BrO}_{3}{ }^{-}$removal $[17,20]$. For example, $100 \%$ $\mathrm{BrO}_{3}{ }^{-}$removal was achieved in the first month and declined to around $5 \%$ removal after 11 months in a pilot with an empty bed contact time of $15 \mathrm{~min}$ [21]. The performance of GAC in most applications is influenced by its surface chemistry [22-24], so the modification of this GAC property, especially surface oxygen functional groups, has been frequently the target of a variety of GAC beneficiation treatments [25]. Oxidation as one of the most conventional modifications is mainly used to introduce carbon-oxygen surface groups in GAC [26]. Some oxidants, such as $\mathrm{HNO}_{3}, \mathrm{O}_{3}$ and $\mathrm{H}_{2} \mathrm{O}_{2}$, have been tested for GAC modification to increase the oxygen surface groups, and results indicated that the oxidation of GAC increased the content of acidic oxygen surface groups and the adsorption capacity of $\mathrm{Hg}, \mathrm{Cd}, \mathrm{Cr}(\mathrm{III}), \mathrm{Cr}(\mathrm{VI})$ and $\mathrm{Cu}(\mathrm{II})$ [26-28]. The oxidation treatment of GAC as a rule was performed mostly using $\mathrm{O}_{2}$ and acid, and rarely with $\mathrm{H}_{2} \mathrm{O}_{2}$. The real situation in practice is the co-presence of $\mathrm{BrO}_{3}{ }^{-}$and $\mathrm{H}_{2} \mathrm{O}_{2}$, while as far as to the authors' knowledge, it has not been known whether the presence of $\mathrm{H}_{2} \mathrm{O}_{2}$ as a modification reagent of GAC can play a positive role in $\mathrm{BrO}_{3}{ }^{-}$adsorption by $\mathrm{GAC}$ during drinking water treatment. However, another possibility could be that the co-presence of $\mathrm{BrO}_{3}{ }^{-}$and $\mathrm{H}_{2} \mathrm{O}_{2}$ may compete the active sites or oxygen-containing functional groups of GAC so that they may negatively impact each other's removal. What is more, the $\mathrm{H}_{2} \mathrm{O}_{2}$ decomposition product oxygen was speculated to cover the active sites on the surface of GAC or block the micropores [29], so that the presence of $\mathrm{H}_{2} \mathrm{O}_{2}$ may decrease $\mathrm{BrO}_{3}{ }^{-}$removal efficiency. Oppositely, the presence of $\mathrm{H}_{2} \mathrm{O}_{2}$ as a strong oxidant to modify $\mathrm{GAC}$ may increase the $\mathrm{BrO}_{3}{ }^{-}$removal, as stated earlier. However, till now it has not yet been investigated whether the co-presence of $\mathrm{H}_{2} \mathrm{O}_{2}$ and $\mathrm{BrO}_{3}{ }^{-}$can improve $\mathrm{BrO}_{3}{ }^{-}$removal by GAC.

The objectives of this study were to assess whether the presence of residual $\mathrm{H}_{2} \mathrm{O}_{2}$ from AOP in the water could improve the removal of $\mathrm{BrO}_{3}{ }^{-}$by GAC and to investigate the mechanism behind it.

\section{Materials and Methods}

\subsection{GAC}

Virgin, pre-loaded and regenerated GAC (Norit ROW 0.8 CAT) was used in this study. The virgin GAC was purchased from Sigma-Aldrich (St. Louis, MO, USA). The pre-loaded and regenerated GAC were collected from Dunea drinking water plant (Bergambacht, The Netherlands). The GAC pre-loaded with natural organic matter was already used for two and half years at the Dunea plant. The particle size of all GACs was $0.8-1.0 \mathrm{~mm}$.

The GAC for the batch experiments was prepared by the following procedures. The GAC was ground and sieved to obtain a particle size ranging from $0.25 \mathrm{~mm}$ to $0.8 \mathrm{~mm}$. After sieving, the GAC was washed with ultra-pure water until the water remained colorless, and finally the GAC was dried at $175^{\circ} \mathrm{C}$ for $72 \mathrm{~h}$ to remove volatile impurities.

\subsection{Water and Chemical Reagents}

The water used in batch experiments was prepared using chemical reagents and deionized water from a Millipore Milli-Q system. Chemicals including sodium bromate $\left(\mathrm{NaBrO}_{3}\right)$, sodium hydroxide $(\mathrm{NaOH})$, concentrated acid $(\mathrm{HCl})$, sodium carbonate $\left(\mathrm{Na}_{2} \mathrm{CO}_{3}\right)$, sodium bicarbonate $\left(\mathrm{NaHCO}_{3}\right)$ and hydrogen peroxide $\left(\mathrm{H}_{2} \mathrm{O}_{2}\right)$ were purchased from Sigma-Aldrich. The $\mathrm{H}_{2} \mathrm{O}_{2}$ solutions were prepared from a $30 \%$ standard solution (Merck, Germany). All chemicals were of analytical grade. All solutions used in this study were prepared using water from a Millipore Milli-Q system. 


\subsection{Batch Experiments}

In a survey of 100 drinking water utilities, $\mathrm{BrO}_{3}{ }^{-}$concentrations were in the range of $<0.016-0.5 \mu \mathrm{mol} / \mathrm{L}$ following ozonation of water containing $0.025-5.36 \mu \mathrm{mol} / \mathrm{L} \mathrm{Br}^{-}[30,31]$. It was decided to investigate the upper value of this range in this study, so $0.5 \mu \mathrm{mol} / \mathrm{L}$ $\mathrm{BrO}_{3}{ }^{-}$was achieved in the batch experiments. Batch experiments were conducted using glass bottles with a volume of $1 \mathrm{~L}$. During all the experiments, the batch reactors were wrapped in thin foil. A $0.052 \mu \mathrm{mol} / \mathrm{L} \mathrm{NaBrO}_{3}$ solution was prepared and $3 \mathrm{~mL}$ was dosed into the batch reactors to obtain a concentration of $0.5 \mu \mathrm{mol} / \mathrm{L} \mathrm{BrO}_{3}{ }^{-}$. The research of Lekkerkerker and $\mathrm{Knol}$ [32] showed that $180 \mu \mathrm{mol} / \mathrm{L} \mathrm{H}_{2} \mathrm{O}_{2}$ dosage was enough to form sufficient hydroxyl radicals in the AOP, so the residual $\mathrm{H}_{2} \mathrm{O}_{2}$ concentration in effluent water of AOP will not exceed $180 \mu \mathrm{mol} / \mathrm{L}$. Hence, $150 \mu \mathrm{mol} / \mathrm{L} \mathrm{H}_{2} \mathrm{O}_{2}$ was dosed into the batch reactors in this study.

As is shown in Figure 1, a series of experiments were performed using 36 batch glass bottles at ambient temperature of $23-27^{\circ} \mathrm{C}$. The GAC dosage was always $5 \mathrm{~g} / \mathrm{L}$, and the $\mathrm{H}_{2} \mathrm{O}_{2}$ and $\mathrm{BrO}_{3}{ }^{-}$concentrations were always $150 \mu \mathrm{mol} / \mathrm{L}$ and $0.5 \mu \mathrm{mol} / \mathrm{L}$, respectively. All the batch reactors with $\mathrm{H}_{2} \mathrm{O}_{2}$ were covered by aluminium foils to prevent potential degradation of $\mathrm{H}_{2} \mathrm{O}_{2}$ by the light.

In experiment $A$ as shown in Figure 1, 16 batch reactors and three different GACs (virgin GAC, regenerated GAC and pre-loaded GAC) were used to investigate the removal of bromate and $\mathrm{H}_{2} \mathrm{O}_{2}$ by GAC with different running time. This experiment involved eight treatment groups (only $\mathrm{H}_{2} \mathrm{O}_{2}$, virgin $\mathrm{GAC}+\mathrm{H}_{2} \mathrm{O}_{2}$, regenerated $\mathrm{GAC}+\mathrm{H}_{2} \mathrm{O}_{2}$, pre-loaded $\mathrm{GAC}+\mathrm{H}_{2} \mathrm{O}_{2}$, only $\mathrm{BrO}_{3}{ }^{-}$, virgin $\mathrm{GAC}+\mathrm{BrO}_{3}{ }^{-}$, regenerated $\mathrm{GAC}+\mathrm{BrO}_{3}{ }^{-}$, and preloaded $\left.\mathrm{GAC}+\mathrm{H}_{2} \mathrm{O}_{2}\right)$. The groups without $\mathrm{GAC}$ were references. Before the experiment started, the three GACs were collected to characterize their surface functional groups. Water samples were collected at $0,10,20,60,120$ and $180 \mathrm{~min}$ for $\mathrm{BrO}_{3}{ }^{-}$and $\mathrm{H}_{2} \mathrm{O}_{2}$ analysis.

In experiment $\mathrm{B}$ as shown in Figure 1, $0.5 \mu \mathrm{mol} / \mathrm{L} \mathrm{BrO}_{3}{ }^{-}$and / or $150 \mu \mathrm{mol} / \mathrm{L} \mathrm{H}_{2} \mathrm{O}_{2}$ was dosed into batch reactors with virgin GAC to investigate whether the presence of residual $\mathrm{H}_{2} \mathrm{O}_{2}$ from AOP improved the removal of $\mathrm{BrO}_{3}{ }^{-}$by GAC. This experiment involved 6 treatment groups $\left(\mathrm{BrO}_{3}{ }^{-}, \mathrm{H}_{2} \mathrm{O}_{2}, \mathrm{BrO}_{3}{ }^{-}+\mathrm{H}_{2} \mathrm{O}_{2}, \mathrm{BrO}_{3}{ }^{-}+\mathrm{GAC}, \mathrm{H}_{2} \mathrm{O}_{2}+\mathrm{GAC}\right.$, and $\left.\mathrm{BrO}_{3}{ }^{-}+\mathrm{H}_{2} \mathrm{O}_{2}+\mathrm{GAC}\right)$. The groups without GAC were references. Water samples were collected from the reactors for the analysis of $\mathrm{BrO}_{3}{ }^{-}$and $\mathrm{H}_{2} \mathrm{O}_{2}$. To identify the consumed/modified oxygen containing surface functional groups during the contact time, GAC samples were collected for the analysis of surface oxygen functional groups at the beginning and the end of the experiment.

To further assess the effect of $\mathrm{H}_{2} \mathrm{O}_{2}$ presence on $\mathrm{BrO}_{3}{ }^{-}$removal in a broad $\mathrm{pH}$ range, batch experiment $C$ was performed using eight batch reactors with virgin $G A C, \mathrm{H}_{2} \mathrm{O}_{2}$ and $\mathrm{BrO}_{3}{ }^{-}$, in different $\mathrm{pH}$ levels ranging from 5.5 to 10 . During the whole experiment, the solutions in batch reactors were not buffered. Every $5 \mathrm{~min}$, solution $\mathrm{pH}$ was measured, and $\mathrm{HCl}$ or $\mathrm{NaOH}$ solution was dropped into batch reactors manually to reach a stable $\mathrm{pH}$ level. Water samples were collected at $0,10,20,60,120,180,240$ and $300 \mathrm{~min}$ for $\mathrm{BrO}_{3}{ }^{-}$ and $\mathrm{H}_{2} \mathrm{O}_{2}$ analysis. Additionally, GAC samples were collected to measure the initial and ending surface functional groups. 


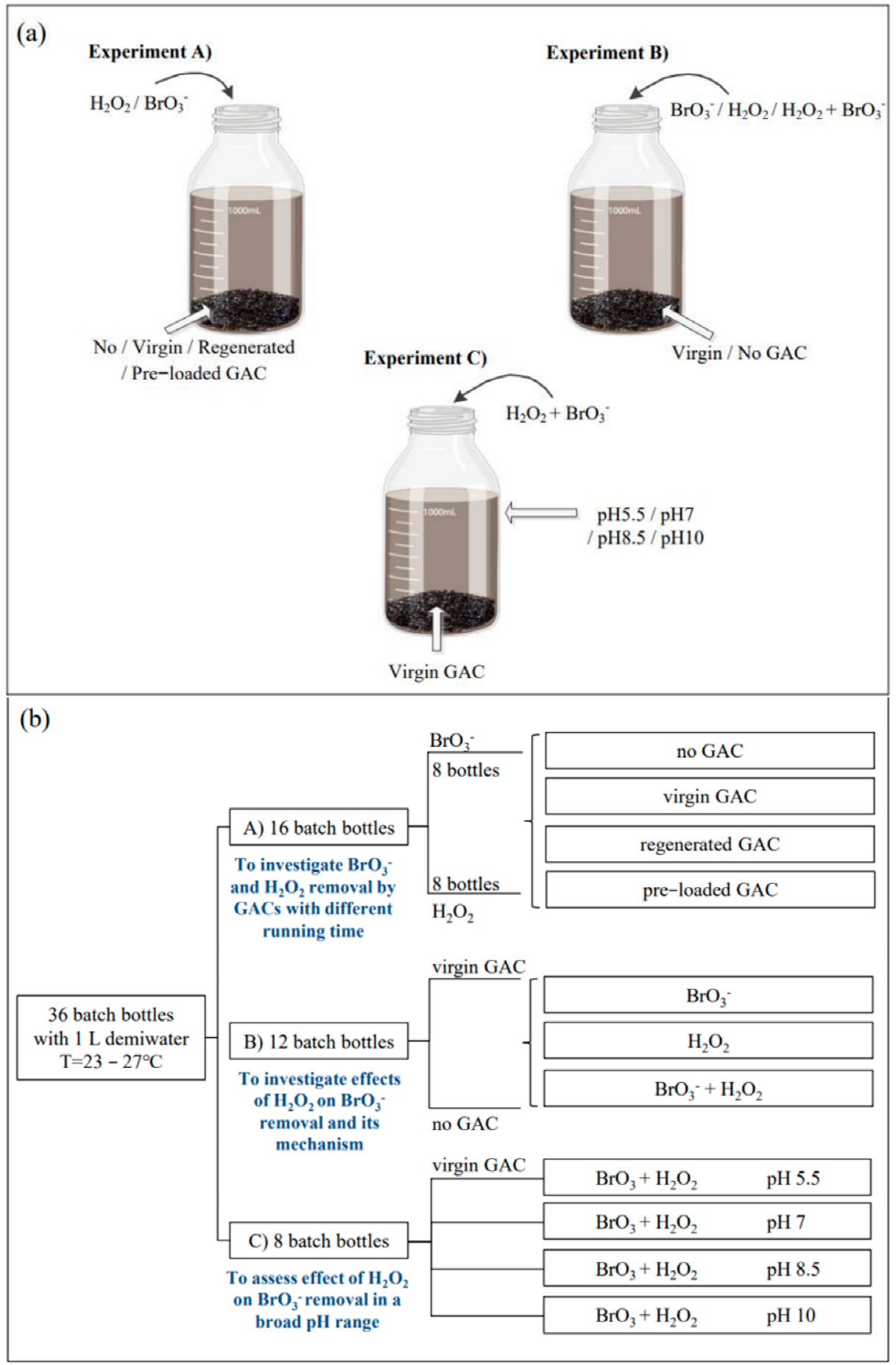

Figure 1. The schematic diagram of the reactor (a) and the flowchart of the experimental plan (b).

\subsection{Analytical Methods}

\subsubsection{Functional Groups Measurement}

The amount of surface acidic and basic functional groups was measured by the Boehm method [33]. Four series of GAC samples $(0.5 \mathrm{~g})$ were added to four flasks $(100 \mathrm{~mL})$. Then, $50 \mathrm{~mL}$ of $0.05 \mathrm{~mol} / \mathrm{L}$ sodium hydrogen carbonate $\left(\mathrm{NaHCO}_{3}\right)$, sodium carbonate $\left(\mathrm{Na}_{2} \mathrm{CO}_{3}\right)$ and sodium hydroxide $(\mathrm{NaOH})$ were added to the flasks, respectively. The flasks were then sealed and stirred at room temperature for $24 \mathrm{~h}$. The GAC samples were then filtrated and carefully washed. All filtrates were collected and subsequently diluted to $100 \mathrm{~mL}$. Then, the diluent was titrated with $0.05 \mathrm{~mol} / \mathrm{L} \mathrm{HCl}$ and the surface oxygenated groups 
were determined according to the following assumptions: $\mathrm{NaOH}$ neutralizes carboxyl, phenolic and lactonic groups. $\mathrm{Na}_{2} \mathrm{CO}_{3}$ neutralizes carboxyl and lactonic groups. $\mathrm{NaHCO}_{3}$ neutralizes carboxyl groups only. The amount of basic surface groups was determined with $0.05 \mathrm{~mol} / \mathrm{L} \mathrm{HCl}$ solution. The filtrate was collected as above, and then titrated with $0.05 \mathrm{~mol} / \mathrm{L} \mathrm{NaOH}$ solution.

\subsubsection{Other Analysis and Measurements}

Hydrogen peroxide test kits (1.18789.0001, VWR Company, Radnor, PA, USA) with a detection range of $0.44-180 \mu \mathrm{mol} / \mathrm{L}$ were used for water-phase $\mathrm{H}_{2} \mathrm{O}_{2}$ measurements because of ease of operation, the rapid decomposition of $\mathrm{H}_{2} \mathrm{O}_{2}$ and accuracy of results. After being filtered through $0.45 \mu \mathrm{m}$ filters, the samples were transferred to a $10 / 20 \mathrm{~mm}$ rectangular cell and measured in a photometer (Spectroquant NOVA 60).

$\mathrm{BrO}_{3}{ }^{-}$was analysed using a Metrohm Schiedam ion chromatograph (SenTix ${ }^{\circledR} 940$ IDS probe, Multi 340i, WTW, Germany) equipped with a suppressed conductivity detector, using an A Supp 16 150/4.0 column, a guard column, and a $100 \mu \mathrm{L}$ sample loop. A $3.75 \mathrm{mM}$ $\mathrm{Na}_{2} \mathrm{CO}_{3}$ and $0.375 \mathrm{mM} \mathrm{NaOH}$ solution was used as the eluent. The eluent flow rate was set at $0.7 \mathrm{~mL} / \mathrm{min}$. $\mathrm{pH}$ was measured with a SenTix ${ }^{\circledR} 940$ (WTW) electrode (Xylem Inc., Weiheim, Germany), both using the WTW Multi 3420 m (Xylem Inc., Weiheim, Germany).

\section{Results and Discussion}

\section{1. $\mathrm{BrO}_{3}{ }^{-}$and $\mathrm{H}_{2} \mathrm{O}_{2}$ Removal by Three GACs with Different Usage Times}

Figure 2 presents $\mathrm{H}_{2} \mathrm{O}_{2}$ and $\mathrm{BrO}_{3}{ }^{-}$removal efficiencies within 180 min by virgin GAC, pre-loaded GAC and regenerated GAC, respectively. As is shown in Figure 2a, among the three kinds of GAC, virgin GAC had the best $\mathrm{BrO}_{3}{ }^{-}$removal capacity (81\%). No $\mathrm{BrO}_{3}{ }^{-}$removal was observed in the batch reactor without GAC, indicating $\mathrm{BrO}_{3}{ }^{-}$ was not self-decomposed or decomposed by microbes in a short experiment period of $180 \mathrm{~min}$. The pre-loaded GAC did not remove $\mathrm{BrO}_{3}{ }^{-}$at all, which is in line with a previous study reporting that $\mathrm{BrO}_{3}{ }^{-}$removal rate by GAC apparently decreased with increasing operation time [34], probably because the active sites or valid functional groups on the surface of GAC were exhausted due to preloading in the preceding two years with natural organic matter present in the drinking water treatment plant [35]. It seems that $3.8 \% \mathrm{BrO}_{3}{ }^{-}$ was removed by regenerated GAC, which is in line with a previous study reporting that, compared with regenerated GAC, virgin $\mathrm{GAC}$ had a better removal effect on $\mathrm{BrO}_{3}{ }^{-}$[36]. This result indicates that the thermal regeneration restored active sites or functional groups on the surface of GAC to some degree. In conclusion, these results indicate that GAC may become invalid for $\mathrm{BrO}_{3}{ }^{-}$removal after a period of running, even after regeneration, in practice. As is shown in Figure $2 b, \mathrm{H}_{2} \mathrm{O}_{2}$ was not decomposed in the absence of GAC within $180 \mathrm{~min}$, indicating that the decrease of $\mathrm{H}_{2} \mathrm{O}_{2}$ in other groups was caused by GAC instead of other factors. No obvious difference was observed between preloaded GAC and virgin GAC groups. $\mathrm{H}_{2} \mathrm{O}_{2}$ removal rate in regenerated GAC group was slightly lower than that in preloaded GAC group. GAC regeneration and recycle slighly decreased $\mathrm{H}_{2} \mathrm{O}_{2}$ removal capacity, but regenerated GAC is still able to effectively quench residual $\mathrm{H}_{2} \mathrm{O}_{2}$. Previous studies showed that GAC can be used to quench the residual $\mathrm{H}_{2} \mathrm{O}_{2}$ after drinking water treatment AOPs, and the catalytic activity of GAC has nothing to do with continuous exposure to hydrogen peroxide, but is related to the physical and chemical properties of the GAC surface [37,38]. 

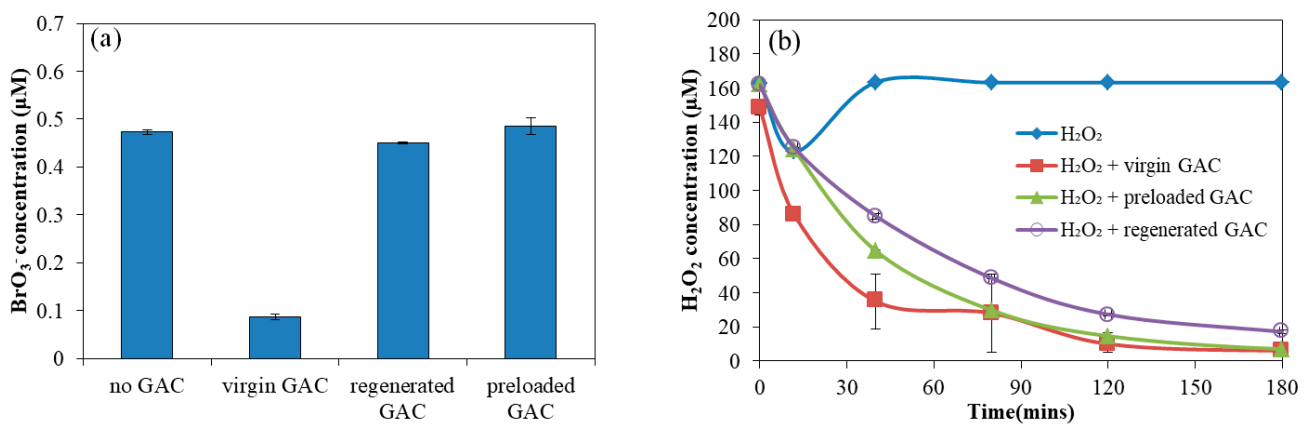

Figure 2. (a) $\mathrm{BrO}_{3}{ }^{-}$and (b) $\mathrm{H}_{2} \mathrm{O}_{2}$ removal by different types of GAC. GAC dosage was $5 \mathrm{~g} / \mathrm{L}$. Initial $\mathrm{BrO}_{3}$ concentration was $0.5 \mu \mathrm{M}$.

\subsection{Surface Functional Groups of Three GACs with Different Usage Times}

Figure 3 presents the acidic and basic functional groups on the surface of three kinds of GAC with different usage times before the $\mathrm{BrO}_{3}{ }^{-}$and $\mathrm{H}_{2} \mathrm{O}_{2}$ removal experiment. Generally, the overall concentrations of acidic and basic functional groups are observed to be in the following order: virgin GAC > regenerated GAC > pre-loaded GAC, although the concentration of basic functional groups on the surface of virgin GAC is the same as that of regenerated GAC, indicating that the virgin GAC contained rich functional groups and the regeneration can recover a portion of functional groups. Usually, regardless of the regeneration method used, the porosity, specific surface area and surface oxygen functional groups on the surface of the regenerated GAC are less than that of the virgin GAC. Mesopores formed during the regeneration are considered to promote the carbon adsorption capacity [39]. Correspondingly, $\mathrm{BrO}_{3}{ }^{-}$removal ability was also recovered after GAC regeneration, but not much (Figure 2). Acid groups are classified to lactonic groups, carboxyl groups and phenolic groups. Among the three acidic functional groups, lactonic groups and phenolic groups on virgin GAC are greater than that on regenerated and pre-loaded GAC. This might also be one of the reasons why virgin GAC reached the highest removal efficiencies of $\mathrm{BrO}_{3}{ }^{-}$and $\mathrm{H}_{2} \mathrm{O}_{2}$ (Figure 2).

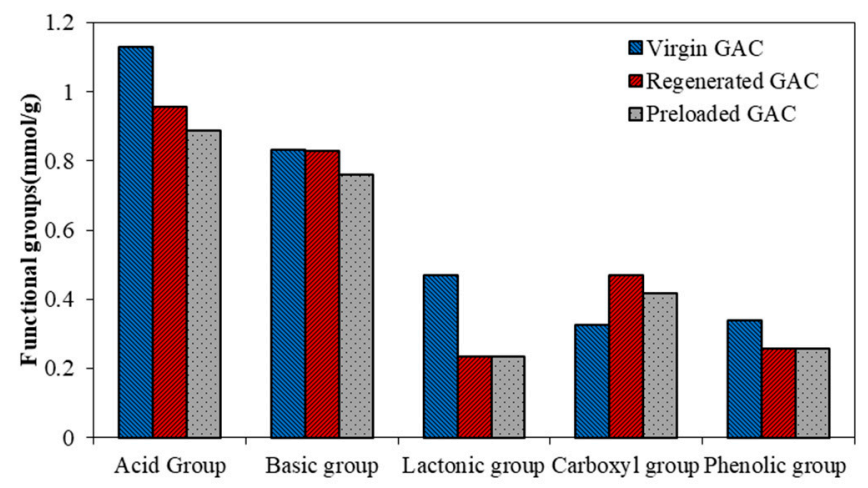

Figure 3. Surface functional groups of three different types of GAC.

\subsection{Effect of $\mathrm{H}_{2} \mathrm{O}_{2}$ on $\mathrm{BrO}_{3}{ }^{-}$Removal by Virgin $\mathrm{GAC}$}

To assess the interaction of $\mathrm{BrO}_{3}{ }^{-}$and $\mathrm{H}_{2} \mathrm{O}_{2}$ removal by virgin $\mathrm{GAC}$, Figure 4 presents the removal of $\mathrm{BrO}_{3}{ }^{-}$and $\mathrm{H}_{2} \mathrm{O}_{2}$ by $5 \mathrm{~g} / \mathrm{L}$ virgin $\mathrm{GAC}$ in the presence and the absence of the other. Figure $4 \mathrm{a}$ shows that the initial $0.5 \mu \mathrm{mol} / \mathrm{L} \mathrm{BrO}_{3}{ }^{-}$was removed $60-80 \%$ by GAC under the presence and absence of $\mathrm{H}_{2} \mathrm{O}_{2}$ in $180 \mathrm{~min}$, respectively. It can be observed that the $\mathrm{BrO}_{3}{ }^{-}$concentration decreased faster in the absence than in the presence of $150 \mu \mathrm{mol} / \mathrm{L}$ $\mathrm{H}_{2} \mathrm{O}_{2}$, that is the presence of $150 \mu \mathrm{mol} / \mathrm{L} \mathrm{H}_{2} \mathrm{O}_{2}$ negatively impacted $\mathrm{BrO}_{3}{ }^{-}$removal by GAC, indicating $150 \mu \mathrm{mol} / \mathrm{L} \mathrm{H}_{2} \mathrm{O}_{2}$ may not successfully modify the surface functional groups of GAC at the ambient temperature. A previous study found that the activated carbon modified with $0.04 \mathrm{~mol} / \mathrm{L}$ hydrogen peroxide at $75^{\circ} \mathrm{C}$ removed $85.6 \%$ cobalt from 
aqueous solution after $1 \mathrm{~h}$, while the activated carbon modified at a lower temperature of $25^{\circ} \mathrm{C}$ removed only $74 \%$ cobalt after $1 \mathrm{~h} \mathrm{[40].} \mathrm{It} \mathrm{further} \mathrm{proves} \mathrm{that} \mathrm{the} \mathrm{modification}$ temperature has a great influence on the physical and chemical properties of the activated carbon surface, and the low temperature environment cannot modify GAC well. Figure $4 \mathrm{~b}$ shows that $150 \mu \mathrm{mol} / \mathrm{L} \mathrm{H}_{2} \mathrm{O}_{2}$ was decomposed fully by GAC and its decomposition in the presence and the absence of $0.5 \mu \mathrm{M} \mathrm{BrO}_{3}{ }^{-}$had no considerable difference during the 180 min contact time $(p>0.05)$, indicating an ignorable influence of $0.5 \mu \mathrm{mol} / \mathrm{L} \mathrm{BrO}_{3}{ }^{-}$on $\mathrm{H}_{2} \mathrm{O}_{2}$ decomposition. In the reference without $\mathrm{GAC}$, both $\mathrm{BrO}_{3}{ }^{-}$and $\mathrm{H}_{2} \mathrm{O}_{2}$ showed steady concentrations, indicating that no self-decomposition took place and the removal of $\mathrm{BrO}_{3}{ }^{-}$ and $\mathrm{H}_{2} \mathrm{O}_{2}$ can be contributed to GAC.
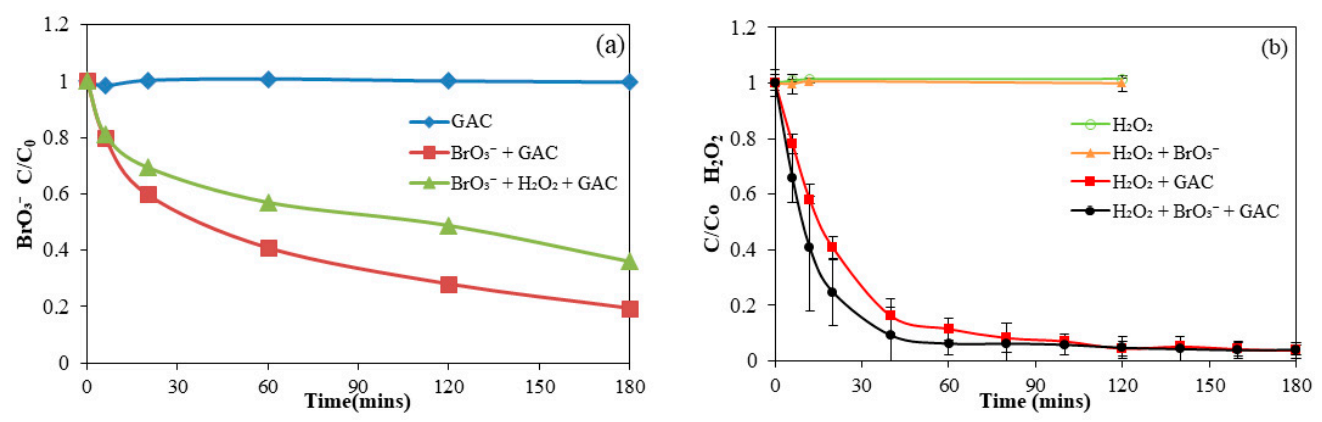

Figure 4. (a) $\mathrm{BrO}_{3}{ }^{-}$and (b) $\mathrm{H}_{2} \mathrm{O}_{2}$ removal by GAC under the co-present condition.

\subsection{The Mechanism of $\mathrm{H}_{2} \mathrm{O}_{2}$ Impact on $\mathrm{BrO}_{3}{ }^{-}$Removal by Virgin $\mathrm{GAC}$}

\subsection{1. $\mathrm{BrO}_{3}{ }^{-}$Removal by Adsorption or Reduction?}

Figure 5 presents the removal of $\mathrm{BrO}_{3}{ }^{-}$by virgin GAC and correspondingly the increase of reaction product $\mathrm{Br}^{-}$, in the presence and absence of $\mathrm{H}_{2} \mathrm{O}_{2}$. Under both situations, the $\mathrm{BrO}_{3}{ }^{-}$concentration gradually decreased, and correspondingly the $\mathrm{Br}^{-}$ concentration gradually increased with time. The molar mass of $\mathrm{BrO}_{3}{ }^{-}$and $\mathrm{Br}^{-}$in the reactor tends to stabilize after a slight decrease in the first $6 \mathrm{~min}$. This slight decrease could be caused by GAC adsorption. The gradual increase of $\mathrm{Br}^{-}$with the decrease of $\mathrm{BrO}_{3}{ }^{-}$ indicates that the removal of $\mathrm{BrO}_{3}{ }^{-}$by virgin $\mathrm{GAC}$ is mainly a reduction process, which might involve redox reactions between surface functional groups and $\mathrm{BrO}_{3}{ }^{-}$. Obviously, the presence of $150 \mu \mathrm{mol} / \mathrm{L} \mathrm{H}_{2} \mathrm{O}_{2}$ significantly inhibited the removal of $\mathrm{BrO}_{3}{ }^{-}$by virgin GAC. Figure 5 showed that the addition of $\mathrm{H}_{2} \mathrm{O}_{2}$ changed the physical and chemical properties of the GAC surface, resulting in a significant decrease in the acidic and basic oxygen-containing functional groups on the GAC surface, thereby reducing the reaction efficiency of the functional groups with $\mathrm{BrO}_{3}{ }^{-}$. When $\mathrm{H}_{2} \mathrm{O}_{2}$ and $\mathrm{BrO}_{3}{ }^{-}$coexist, there may be competition for GAC oxygen-containing functional groups and adsorption active sites, which is one of the reasons why $\mathrm{BrO}_{3}{ }^{-}$removal was inhibited by $\mathrm{H}_{2} \mathrm{O}_{2}$. In addition, bromine mass loss in $\mathrm{BrO}_{3}{ }^{-}$and $\mathrm{Br}^{-}$is observed due to the presence of $\mathrm{H}_{2} \mathrm{O}_{2}$, by comparing Figure 5a,b. During $\mathrm{H}_{2} \mathrm{O}_{2}$ decomposition, a small amount of $\mathrm{OH}$ - can be generated [41]. The $\mathrm{OH}$. can further oxidize $\mathrm{Br}^{-}$into intermediate products, such as $\mathrm{HOBr}$ and $\mathrm{BrO}^{-}$[42], which could explain the bromine mass loss under the situation of $\mathrm{H}_{2} \mathrm{O}_{2}$ addition. 

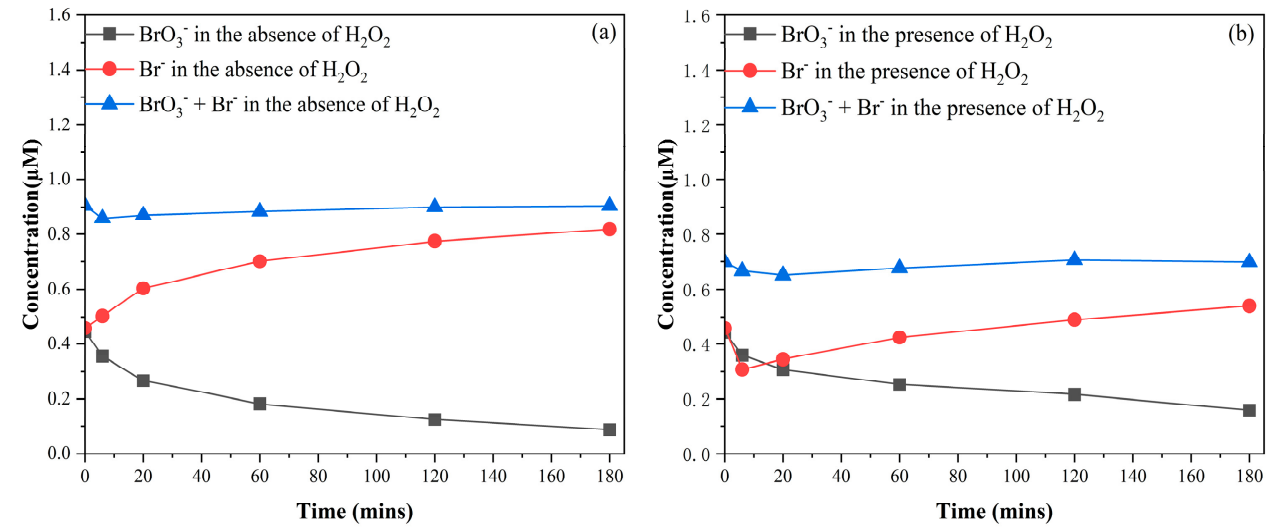

Figure 5. $\mathrm{BrO}_{3}^{-}, \mathrm{Br}^{-}$, and $\mathrm{BrO}_{3}{ }^{-}+\mathrm{Br}^{-}$concentration in the absence and presence of $\mathrm{H}_{2} \mathrm{O}_{2}$. (a) with $\mathrm{H}_{2} \mathrm{O}_{2}$, (b) without $\mathrm{H}_{2} \mathrm{O}_{2}$.

\subsubsection{Modification of GAC Surface Functional Groups by $\mathrm{H}_{2} \mathrm{O}_{2}$}

The surface oxygen-containing functional groups of initial GAC and the modified GAC after contacting with $\mathrm{BrO}_{3}{ }^{-}$and $\mathrm{H}_{2} \mathrm{O}_{2}$ are presented in Figure 6. It is observed that both $\mathrm{H}_{2} \mathrm{O}_{2}$ alone and $\mathrm{BrO}_{3}{ }^{-}$alone consumed acid groups and basic groups, indicating the presence of $\mathrm{H}_{2} \mathrm{O}_{2}$ consumed oxygen-containing surface functional groups with $\mathrm{BrO}_{3}{ }^{-}$instead of provided more functional groups. Therefore, the $\mathrm{H}_{2} \mathrm{O}_{2}$ concentration of $150 \mu \mathrm{mol} / \mathrm{L}$ could be too low to effectively modify GAC oxygen-containing surface functional groups. Among the three acid groups, both the amount of carboxyl groups and phenolic groups did not change significantly after different reactions and the main change lay in lactonic groups, indicating that $\mathrm{H}_{2} \mathrm{O}_{2}$ mainly reacted with lactonic groups. The functional group modification by $\mathrm{H}_{2} \mathrm{O}_{2}$ can be explained as follows.

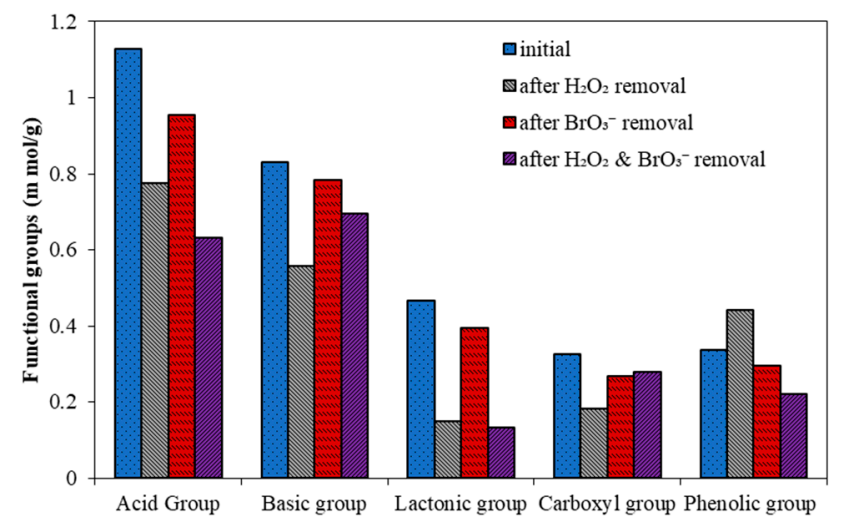

Figure 6. Surface functional groups on the initial and modified GAC.

$\mathrm{H}_{2} \mathrm{O}_{2}$ has a property of electrophilic attacking, so $\mathrm{H}_{2} \mathrm{O}_{2}$ attacks the unsaturated bonds of $\mathrm{C}=\mathrm{C}$ by electrophilic addition and introduces the phenolic groups [43], as shown in Equation (1). In a previous study [43], around $1.47 \mathrm{~mol} / \mathrm{L} \mathrm{H}_{2} \mathrm{O}_{2}$ was used to modify activated carbon at $60^{\circ} \mathrm{C}$ for $2 \mathrm{~h}$ and the modification treatment increased the formation of carboxyl groups and carbonyl groups but decreased the formation of phenolic groups, which was explained by the fact that phenolic groups formed in Equation (1) could be further oxidized to carboxyl groups by esterification and dehydration as shown in Equations (2) and (3). A previous study [44] showed that different from the steady rise of carboxyl groups and lactonic groups, the concentration of phenolic groups first increased and then decreased with the increase of $\mathrm{H}_{2} \mathrm{O}_{2}$ concentration, which could be caused by the fact that the dehydration of phenolic groups became faster than the formation of phenolic groups with the increase of oxidation ability. Therefore, the low $\mathrm{H}_{2} \mathrm{O}_{2}$ concentration, an environmentally relevant concentration, in this study might be not enough to further 
conduct the following two steps reactions, dehydration and esterification, as shown in Equations (2) and (3), which might explain the increase of phenolic groups instead of carboxyl group. In conclusion, an environmentally relevant concentration of $\mathrm{H}_{2} \mathrm{O}_{2}$ from AOP cannot significantly increase the concentrations of carboxyl and lactonic groups due to the limited oxidation ability.

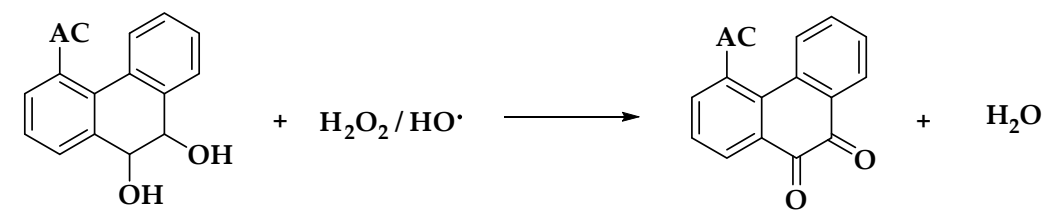<smiles>Cc1ccc2c(c1C(=O)O)C(O)C(O)c1ccccc1-2</smiles><smiles>Cc1cccc(C(=O)OCC(=O)O)c1-c1ccccc1C(=O)O</smiles>

\subsection{Effect of $\mathrm{pH}$ on $\mathrm{BrO}_{3}{ }^{-}$and $\mathrm{H}_{2} \mathrm{O}_{2}$ Removal}

The removal of $\mathrm{BrO}_{3}{ }^{-}$and $\mathrm{H}_{2} \mathrm{O}_{2}$ by virgin GAC under different $\mathrm{pH}$ conditions is shown in Figure 7. At pH 5.5 and 7, $\mathrm{BrO}_{3}{ }^{-}$concentration decreased sharply within the first $50 \mathrm{~min}$, and then remained constant. In contrast, $\mathrm{BrO}_{3}{ }^{-}$concentrations slowly decreased within the whole $300 \mathrm{~min}$ and did not arrive at an equilibrium status at $\mathrm{pH} 8.5$ and 10 . Therefore, $\mathrm{BrO}_{3}{ }^{-}$removal efficiency was higher at the acidic and neutral conditions than at the basic condition, which seems in conflict with a previous study [45]. This is probably because (1) $\mathrm{BrO}_{3}{ }^{-}$is a strong oxidizer under low $\mathrm{pH}$ conditions, and its reactivity is in direct proportion to the square of the proton concentration [46]; (2) as $\mathrm{pH}$ decreases, the protonation of surface functional groups of activated carbon or dissociation of $\mathrm{OH}^{-}$makes the material surface electropositive, resulting in electrostatic attraction of $\mathrm{BrO}_{3}{ }^{-}$[45]. As for $\mathrm{H}_{2} \mathrm{O}_{2}$, with the increase of $\mathrm{pH}, \mathrm{H}_{2} \mathrm{O}_{2}$ decomposition was more efficient. At $\mathrm{pH}$ 10, almost all $\mathrm{H}_{2} \mathrm{O}_{2}$ was removed while only $64 \% \mathrm{H}_{2} \mathrm{O}_{2}$ was removed at $\mathrm{pH}$ 5.5. The results indicate that a higher $\mathrm{pH}$ is favourable to $\mathrm{H}_{2} \mathrm{O}_{2}$ removal in GAC filters during drinking water treatment.
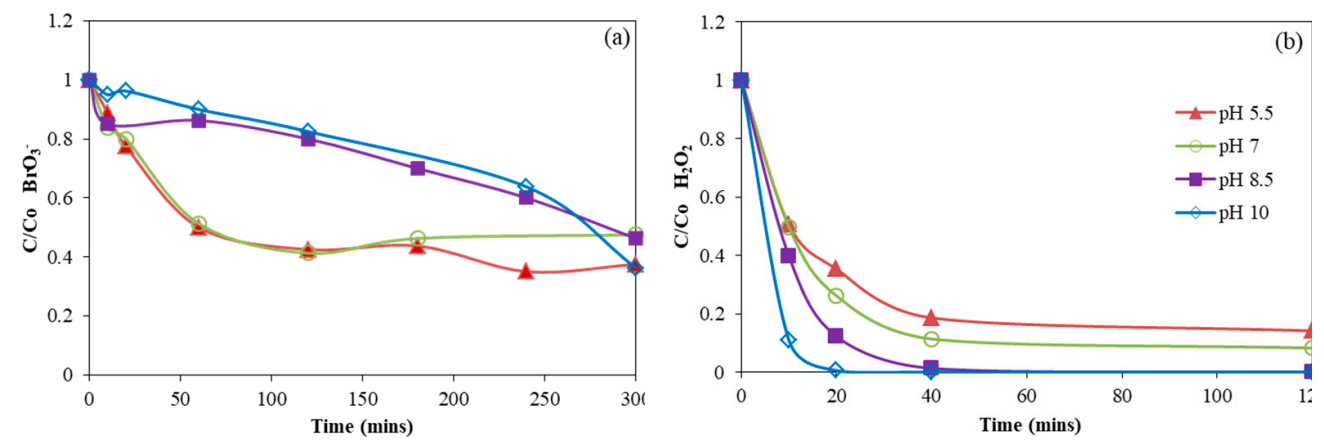

Figure 7. The removal of (a) $\mathrm{BrO}_{3}{ }^{-}$and (b) $\mathrm{H}_{2} \mathrm{O}_{2}$ at different $\mathrm{pH}$ by virgin GAC.

Figure 8 presents the effect of $\mathrm{pH}$ on surface functional groups' modification by $\mathrm{H}_{2} \mathrm{O}_{2}$. With the increase of $\mathrm{pH}$, the surface acid groups decreased from $1 \mathrm{mmol} / \mathrm{g}$ to $0.7 \mathrm{mmol} / \mathrm{g}$ 
in the $\mathrm{pH}$ range of 5.5-7 and then became stable in the $\mathrm{pH}$ range of 7-10. In contrast, the basic group greatly increased with the increase of $\mathrm{pH}$ from 5.5 to 10 . At $\mathrm{pH} 10$, even the basic groups reached $1.2 \mathrm{mmol} / \mathrm{g}$, higher than the initial level of $0.8 \mathrm{mmol} / \mathrm{g}$. With regard to the three acid groups, as the $\mathrm{pH}$ increased, the lactonic groups and phenolic groups presented a notable decrease and a slight decrease respectively, while the carboxyl groups did not show regular changes.

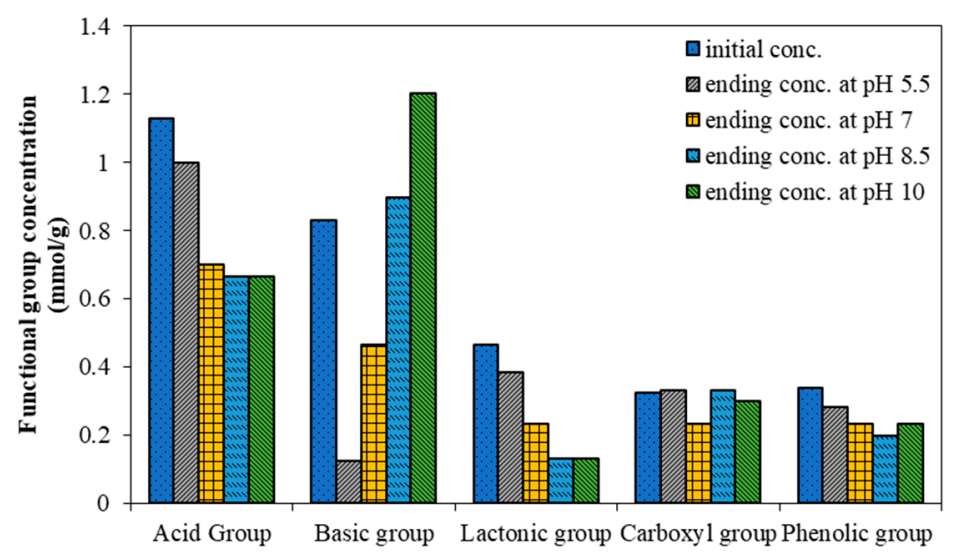

Figure 8. Surface functional groups of the modified oxidized GAC under different $\mathrm{pH}$ levels.

It is reasonable that the change trends of the acid groups and the basic groups with $\mathrm{pH}$ change were caused by acid-base neutralization. What is more, with the increase of $\mathrm{pH}$, the basic groups were observed to increase (Figure 8), and simultaneously the $\mathrm{H}_{2} \mathrm{O}_{2}$ removal efficiency also increased (Figure 7), which is in line with previous studies reporting that the basic groups enhanced the $\mathrm{H}_{2} \mathrm{O}_{2}$ removal [35]. More specifically, the decrease of lactonic groups might be explained by the fact that the lactonic groups produced by the esterification reaction between carboxyl groups and phenolic groups decreased with the increase of $\mathrm{pH}$.

\section{Conclusions}

Virgin GAC has the most acidic and basic surface functional groups, and correspondingly it presented the highest $\mathrm{BrO}_{3}{ }^{-}$removal. However, GAC hardly remove $\mathrm{BrO}_{3}{ }^{-}$ anymore after two years running and thermal regeneration in this study. In our experiments, $5 \mathrm{~g} / \mathrm{L} \mathrm{GAC}$ decreased $\mathrm{H}_{2} \mathrm{O}_{2}$ from $150 \mu \mathrm{mol} / \mathrm{L}$ to $<3 \mu \mathrm{mol} / \mathrm{L}$ within $80 \mathrm{~min}$ and the removal efficiency was not evidently impacted by GAC running time or regeneration.

The presence of $150 \mu \mathrm{mol} / \mathrm{L} \mathrm{H}_{2} \mathrm{O}_{2}$ inhibited $\mathrm{BrO}_{3}{ }^{-}$removal by virgin GAC, which could be explained by the fact that $\mathrm{H}_{2} \mathrm{O}_{2}$ competed oxygen-containing functional groups with $\mathrm{BrO}_{3}{ }^{-} . \mathrm{H}_{2} \mathrm{O}_{2}$ removal efficiency was hardly impacted by the presence of $0.5 \mu \mathrm{mol} / \mathrm{L} \mathrm{BrO}_{3}{ }^{-}$.

Redox reactions between $\mathrm{BrO}_{3}{ }^{-}$and surface functional groups played a dominant role in $\mathrm{BrO}_{3}{ }^{-}$removal by GAC, and a small amount of $\mathrm{BrO}_{3}{ }^{-}$was removed by GAC adsorption.

$\mathrm{BrO}_{3}{ }^{-}$removal efficiency was higher at acidic and neutral conditions than at basic conditions. In contrast, $\mathrm{H}_{2} \mathrm{O}_{2}$ removal efficiency was increased with $\mathrm{pH}$ increase, which could be explained by the increase of alkaline surface functional groups with the increase of $\mathrm{pH}$.

Author Contributions: Conceptualization, F.W. and L.W.; methodology, F.W. and L.W.; Investigation, F.W. and L.Z.; writing — original draft preparation, F.W. and L.Z.; writing—review and editing, L.W. and J.P.v.d.H.; supervision, J.P.v.d.H.; project administration, F.W. and J.P.v.d.H.; funding acquisition, F.W. and J.P.v.d.H. All authors have read and agreed to the published version of the manuscript.

Funding: This research was funded by State Key Laboratory of Pollution Control and Resource Reuse Foundation, grant number PCRRF19003.

Institutional Review Board Statement: Not applicable. 
Informed Consent Statement: Not applicable.

Acknowledgments: This study was financially supported by State Key Laboratory of Pollution Control and Resource Reuse Foundation (No. PCRRF19003).

Conflicts of Interest: The authors declare no conflict of interest.

\section{References}

1. Lekkerkerker, K.; Scheideler, J.; Maeng, S.K.; Ried, A.; Verberk, J.Q.J.C.; Knol, A.H.; Amy, G.; Van Dijk, J.C. Advanced oxidation and artificial recharge: A synergistic hybrid system for removal of organic micropollutants. Water Sci. Technol. Water Supply 2009, 9, 643-651. [CrossRef]

2. Oller, I.; Malato, S.; Sánchez-Pérez, J.A. Combination of Advanced Oxidation Processes and biological treatments for wastewater decontamination-A review. Sci. Total Environ. 2011, 409, 4141-4166. [CrossRef] [PubMed]

3. Sgroi, M.; Snyder, S.A.; Roccaro, P. Comparison of AOPs at pilot scale: Energy costs for micro-pollutants oxidation, disinfection by-products formation and pathogens inactivation. Chemosphere 2021, 273, 128527. [CrossRef]

4. Guan, C.; Jiang, J.; Pang, S.; Zhou, Y.; Gao, Y.; Li, J.; Wang, Z. Formation and control of bromate in sulfate radical-based oxidation processes for the treatment of waters containing bromide: A critical review. Water Res. 2020, 176, 115725. [CrossRef] [PubMed]

5. Farzaneh, H.; Loganathan, K.; Saththasivam, J.; McKay, G. Ozone and ozone/hydrogen peroxide treatment to remove gemfibrozil and ibuprofen from treated sewage effluent: Factors influencing bromate formation. Emerg. Contam. 2020, 6, 225-234. [CrossRef]

6. Ahmad, M.K.; Zubair, H.; Mahmood, R. DNA damage and DNA-protein cross-linking induced in rat intestine by the water disinfection by-product potassium bromate. Chemosphere 2013, 91, 1221-1224. [CrossRef]

7. WHO. Guidelines for Drinking-Water Quality; World Health Organization: Geneva, Switzerland, 1993.

8. US Environmental Protection Agency. Guidelines for Carcinogen Risk Assessment; US Environmental Protection Agency: Washington, DC, USA, 2005.

9. EU. Councial Directive 98/83/EC of 3 November 1998 on the Quality of Water Intended for Human Consumption. Off. J. Eur. Communities 1998, 5, L330. Available online: https:/ / eur-lex.europa.eu/legal-content/EN/ALL/?uri=CELEX:31998L0083 (accessed on 6 September 2021).

10. Yu, J.; Wang, Y.; Wang, Q.; Wang, Z.; Zhang, D.; Yang, M. Implications of bromate depression from $\mathrm{H}_{2} \mathrm{O}_{2}$ addition during ozonation of different bromide-bearing source waters. Chemosphere 2020, 252, 126596. [CrossRef]

11. Bourgin, M.; Borowska, E.; Helbing, J.; Hollender, J.; Kaiser, H.P.; Kienle, C.; McArdell, C.S.; Simon, E.; von Gunten, U. Effect of operational and water quality parameters on conventional ozonation and the advanced oxidation process $\mathrm{O} 3 / \mathrm{H}_{2} \mathrm{O}_{2}$ : Kinetics of micropollutant abatement, transformation product and bromate formation in a surface water. Water Res. 2017, 122, 234-245. [CrossRef] [PubMed]

12. Wang, F.; van Halem, D.; Liu, G.; Lekkerkerker-Teunissen, K.; van der Hoek, J.P. Effect of residual $\mathrm{H}_{2} \mathrm{O}_{2}$ from advanced oxidation processes on subsequent biological water treatment: A laboratory batch study. Chemosphere 2017, 185, 637-646. [CrossRef]

13. Wang, F.; van Halem, D.; Ding, L.; Bai, Y.; Lekkerkerker-Teunissen, K.; van der Hoek, J.P. Effective removal of bromate in nitrate-reducing anoxic zones during managed aquifer recharge for drinking water treatment. Water Res. 2018, 130, 88-97. [CrossRef]

14. Jahan, B.N.; Li, L.; Pagilla, K.R. Fate and reduction of bromate formed in advanced water treatment ozonation systems: A critical review. Chemosphere 2021, 266, 128964. [CrossRef] [PubMed]

15. Kruithof, J.C.; Kamp, P.C.; Martijn, B.J. UV $/ \mathrm{H}_{2} \mathrm{O}_{2}$ treatment: A practical solution for organic contaminant control and primary disinfection. Ozone Sci. Eng. 2007, 29, 273-280. [CrossRef]

16. Wen, G.; Wang, S.; Wang, T.; Feng, Y.; Chen, Z.; Lin, W.; Huang, T.; Ma, J. Inhibition of bromate formation in the O3/PMS process by adding low dosage of carbon materials: Efficiency and mechanism. Chem. Eng. J. 2020, 402, 126207. [CrossRef]

17. Zhang, Y.Q.; Wu, Q.P.; Zhang, J.M.; Yang, X.H. Removal of bromide and bromate from drinking water using granular activated carbon. J. Water Health 2015, 13, 73-78. [CrossRef]

18. Xu, J.; Gao, N.; Zhao, D.; An, N.; Li, L.; Xiao, J. Bromate reduction and reaction-enhanced perchlorate adsorption by FeCl3impregnated granular activated carbon. Water Res. 2019, 149, 149-158. [CrossRef]

19. Cai, J.; Zhang, Y.P. Enhanced Reduction of Bromate from Water by AC/S-nZVI: Performance and Mechanism. J. Environ. Eng. 2020, 146, 04020107. [CrossRef]

20. Kirisits, M.J.; Snoeyink, V.L.; Kruithof, J.C. The reduction of bromate by granular activated carbon. Water Res. 2000, 34, 4250-4260. [CrossRef]

21. Huang, W.J.; Chen, L.Y. Assessing the effectiveness of ozonation followed by GAC filtration in removing bromate and assimilable organic carbon. Environ. Technol. 2004, 25, 403-412. [CrossRef]

22. Bury, N.A.; Mumford, K.A.; Stevens, G.W. The electro-Fenton regeneration of Granular Activated Carbons: Degradation of organic contaminants and the relationship to the carbon surface. J. Hazard. Mater. 2021, 416, 125792. [CrossRef] [PubMed]

23. Palliyarayil, A.; Saini, H.; Vinayakumar, K.; Selvarajan, P.; Vinu, A.; Kumar, N.S.; Sil, S. Advances in porous material research towards the management of air pollution. Emerg. Mater. 2021, 4, 607-643. [CrossRef] 
24. Tang, L.; Ma, X.Y.; Wang, Y.; Zhang, S.; Zheng, K.; Wang, X.C.; Lin, Y. Removal of trace organic pollutants (pharmaceuticals and pesticides) and reduction of biological effects from secondary effluent by typical granular activated carbon. Sci. Total Environ. 2020, 749, 141611. [CrossRef]

25. Mariana, M.; Abdul Khalil, H.P.S.; Mistar, E.M.; Yahya, E.B.; Alfatah, T.; Danish, M.; Amayreh, M. Recent advances in activated carbon modification techniques for enhanced heavy metal adsorption. J. Water Process Eng. 2021, 43, 102221. [CrossRef]

26. Jaramillo, J.; Álvarez, P.M.; Gómez-Serrano, V. Oxidation of activated carbon by dry and wet methods surface chemistry and textural modifications. Fuel Process. Technol. 2010, 91, 1768-1775. [CrossRef]

27. Park, S.-J.; Kim, B.-J. Influence of oxygen plasma treatment on hydrogen chloride removal of activated carbon fibers. J. Colloid Interface Sci. 2004, 275, 590-595. [CrossRef]

28. Kim, D.W.; Wee, J.H.; Yang, C.M.; Yang, K.S. Efficient removals of $\mathrm{Hg}$ and Cd in aqueous solution through $\mathrm{NaOH}-\mathrm{modified}$ activated carbon fiber. Chem. Eng. J. 2020, 392, 123768. [CrossRef]

29. Bohli, T.; Ouederni, A. Improvement of oxygen-containing functional groups on olive stones activated carbon by ozone and nitric acid for heavy metals removal from aqueous phase. Environ. Sci. Pollut. Res. 2016, 23, 15852-15861. [CrossRef] [PubMed]

30. Butler, R.; Godley, A.; Lytton, L.; Cartmell, E. Bromate environmental contamination: Review of impact and possible treatment. Crit. Rev. Environ. Sci. Technol. 2005, 35, 193-217. [CrossRef]

31. Kirisits, M.J.; Snoeyink, V.L. Reduction of bromate in a BAC filter. J. Am. Water Work. Assoc. 1999, 91, 74-84. [CrossRef]

32. Lekkerkerker-Teunissen, K.; Chekol, E.T.; Maeng, S.K.; Ghebremichael, K.; Houtman, C.J.; Verliefde, A.R.D.; Verberk, J.Q.J.C.; Amy, G.L.; van Dijk, J.C. Pharmaceutical removal during managed aquifer recharge with pretreatment by advanced oxidation. Water Sci. Technol. Water Supply 2012, 12, 755-767. [CrossRef]

33. Yang, S.; Li, L.; Xiao, T.; Zheng, D.; Zhang, Y. Role of surface chemistry in modified ACF (activated carbon fiber)-catalyzed peroxymonosulfate oxidation. Appl. Surf. Sci. 2016, 383, 142-150. [CrossRef]

34. Huang, W.J.; Peng, H.S.; Peng, M.Y.; Chen, L.Y. Removal of bromate and assimilable organic carbon from drinking water using granular activated carbon. Water Sci. Technol. 2004, 50, 73-80. [CrossRef]

35. Huang, W.J.; Chen, C.Y.; Peng, M.Y. Adsorption/reduction of bromate from drinking water using GAC: Effects on carbon characteristics and long-term pilot study. Water SA 2004, 30, 369-375. [CrossRef]

36. Siddiqui, M.; Zhai, W.Y.; Amy, G.; Mysore, C. Bromate ion removal by activated carbon. Water Res. 1996, 30, 1651-1660. [CrossRef]

37. Li, J.; Zamyadi, A.; Hofmann, R. Effect of granular activated carbon type and age on quenching $\mathrm{H}_{2} \mathrm{O}_{2}$ residuals after $\mathrm{UV} / \mathrm{H}_{2} \mathrm{O}_{2}$ drinking water treatment. J. Water Supply Res. Technol. AQUA 2016, 65, 28-36. [CrossRef]

38. Kurniawan, T.A.; Lo, W.-h. Removal of refractory compounds from stabilized landfill leachate using an integrated $\mathrm{H}_{2} \mathrm{O}_{2}$ oxidation and granular activated carbon (GAC) adsorption treatment. Water Res. 2009, 43, 4079-4091. [CrossRef]

39. Han, X.; Wishart, E.; Zheng, Y. A comparison of three methods to regenerate activated carbon saturated by diesel fuels. Can. J. Chem. Eng. 2014, 92, 884-891. [CrossRef]

40. Liu, Z.; Zhang, Y.G.; Han, B.; Tan, Z.C.; Li, Q.H. Adsorption of cobalt (III) by $\mathrm{HCl}$ and $\mathrm{H}_{2} \mathrm{O}_{2}$ modified activated carbon. Int. J. Environ. Pollut. 2018, 63, 192-205. [CrossRef]

41. Rey, A.; Zazo, J.A.; Casas, J.A.; Bahamonde, A.; Rodriguez, J.J. Influence of the structural and surface characteristics of activated carbon on the catalytic decomposition of hydrogen peroxide. Appl. Catal. A Gen. 2011, 402, 146-155. [CrossRef]

42. von Gunten, U. Ozonation of drinking water: Part II. Disinfection and by-product formation in presence of bromide, iodide or chlorine. Water Res. 2003, 37, 1469-1487. [CrossRef]

43. Gu, L.; Wang, D.; Deng, R.; Liu, H.; Ai, H. Effect of surface modification of activated carbon on its adsorption capacity for bromate. Desalin. Water Treat. 2013, 51, 2592-2601. [CrossRef]

44. Zhang, D.F.; Lu, W.; Wang, P.P.; Yang, L.L.; Li, C.X.; Zeng, X.D. Effect of wet oxidized modification on oxygen-containing functional groups of activated carbon fibers. Meitan Xuebao 2008, 33, 439-443.

45. Yan, H.; Du, X.; Li, P.; Yu, S.; Tang, Y. Adsorption of bromate from aqueous solutions by modified granular activated carbon: Batch and column tests. Ozone Sci. Eng. 2015, 37, 357-370. [CrossRef]

46. Huang, W.J.; Cheng, Y.L. Effect of characteristics of activated carbon on removal of bromate. Sep. Purif. Technol. 2008, 59, 101-107. [CrossRef] 